\title{
Effect of exogenous salicylic acid under irrigation withholding at different growth stages in wheat (Triticum aestivum $\mathrm{L}$.)
}

\author{
Dabzad MA ${ }^{1}$, Moghadam HRT ${ }^{1}$, Zahedi $\mathrm{H}^{* 2}$ \\ ${ }^{I}$ Department of Agronomy, College of Agriculture,Varamin-Pishva Branch, Islamic Azad University, Varamin, \\ Iran ${ }^{2}$ Department of Agronomy and Plant Breeding, Islamshahr Branch, Islamic Azad University, Islamshahr, \\ Iran
}

[Received: November 17, Accepted: December 3, 2014]

\begin{abstract}
Salicylic acid (SA), an endogenous plant growth regulator has been found to generate a wide range of metabolic and physiological responses in plants affecting their growth and development. In order to study effect of salicylic acid foliar application and limited irrigation on quantitative and qualitative characteristics of wheat, this experiment was conducted at Varamin, Iran during 2014 growing season. The experimental design was laid out in a randomized complete block with a split plots arrangement of treatments in three replications. Main plots included four different levels of irrigation (complete irrigation, irrigation withholding at stem elongation stage, irrigation withholding at flowering stage and irrigation withholding at seed filling period stage) and different concentration of foliar application of salicylic acid ( 0 , 150 and $300 \mu \mathrm{M}$ ) were allocated to subplots. The results showed that irrigation withholding conditions in different growth stages significantly decreased seed yield, RWC and total chlorophyll but by contrast increased membrane stability, proline content, SOD and CAT enzymes activity and also lipid and protein peroxidation. Salicylic acid foliar application had positive effect on all attributes in this experiment. In general, the results of the present study indicate that usage of salicylic acid reduces the harmful effects of water deficit stress and increases resistance to drought stress in wheat plant.
\end{abstract}

Keywords: Salicylic acid, wheat, irrigation withholding, SOD, CAT.

\section{INTRODUCTION}

Water is essential for plant growth and agricultural productivity is solely dependent upon water and it is necessary from seed germination to plant maturation [1]. Drought stress is one of the most important abiotic stress factors which are generally accompanied by heat stress in dry season [2]. Plants often suffer from water deficit stress, and the severity of the resulting damage varies depending on the intensity and duration of the stress. Other than the apparent effects of drought stress, the effects of water deficit are not well understood at the biochemical and molecular levels [3,4,5]. Under different conditions particularly environmental stress, reactive oxygen species, such as superoxide anion radicals, hydrogen peroxide, and hydroxyl radicals, are generated [6]. Reactive oxygen species can damage essential membrane lipids as well as proteins and nucleic acids [7]. However, under conditions of environmental stress, production of ROS can increase and endogenous protective activity may then become inadequate. Various associations between water stress and endogenous levels of water-soluble antioxidants have been described [8]. Antioxidant enzymes ascorbate peroxidase (POX), glutathione reductase and non-specific POX also increased significantly under water stress [9]. Various physiological practices are applied to alleviate the adverse effects of water deficit stress on the normal functioning of plants. For example, plant growth regulators have been applied to plants as a means of improving the growing of those plants. Indeed, there is evidence that the proper application of plant growth regulators can increase plant tolerance to environmental stresses such as drought, heavy metals, salinity, chilling and water-logging [10,11]. Salicylic acid (SA), a plant Phenolic is now considered as a hormone-like endogenous regulator and its role in the defense mechanisms against biotic and a biotic stress has been well documented $[12,13]$. When applied exogenously at suitable concentrations, SA was found to enhance the efficiency of antioxidant system in plants [14]. SA was found to enhance the activities of antioxidant enzymes, (CAT), peroxidase (POX) and superoxide dismutase (SOD), when sprayed exogenously to the drought stressed plants of L. esculentum [10] or to the salinity stressed plants of B. juncea [15]. Krantev et al [16] reported the exogenous application of salicylic acid enhanced the activities of antioxidant enzymes ascorbate peroxidase (APX) and SOD in maize plants. The primary objective of the present investigation was to examine the effect of drought stress and salicylic acid on the activities of different antioxidant enzymes and other biochemical exchanges in leaves of wheat. The work was aimed also whether a foliar supply of salicylic acid to plant might be a strategy for increasing the drought stress tolerance.

\section{MATERIALS AND METHODS}


The experiment was conducted at Varamin, Iran during 2014 growing season. Site of study was situated at $31^{\circ} 519 \mathrm{E}$ and $20^{\circ} 359 \mathrm{~N}$ and $1050 \mathrm{~m}$ above sea level. Latitude and longitude of research place were $35^{\circ}, 19^{\prime} \mathrm{N}$ and $51^{\circ}, 39^{\prime} \mathrm{E}$, respectively and site of study was located $900 \mathrm{~m}$ above sea level. Before beginning of experiment, soil samples were taken in order to determine the physical and chemical properties. A composite soil sample was collected at a depth of $0-30 \mathrm{~cm}$. Details of soil properties are shown in Table 1. After plow and disk, plots were prepared. The experimental design was carried out in a randomized complete block with a split plot arrangement of treatments in three replications. Main plots included four different levels of irrigation (complete irrigation, irrigation withholding at stem elongation stage, irrigation withholding at flowering stage and irrigation withholding at seed filling period stage) and different concentration of foliar application of salicylic acid $(0,150$ and $300 \mu \mathrm{M})$ were allocated to subplots. Each sub plot consisted 12 rows, $5 \mathrm{~m}$ long with $20 \mathrm{~cm}$ spaced between rows and $5 \mathrm{~cm}$ distance between plants on the rows, $2 \mathrm{~m}$ alley was kept to eliminate all influence of lateral water movement. Polyethylene pipeline was performed for control of irrigation as dropping irrigation. After seed sowing, irrigation was applied as required during the growing season. The foliar application of salicylic acid was applied with a pressurized backpack sprayer (12 l capacity) calibrated to deliver $10001 \mathrm{ha}^{-1}$ of spray solution. Sprayer was equipped with a spiral solid cone spray nozzle. At the end of growing season crop were harvested and seed yield was assayed. One week after irrigation withholding in different growth stages initiation leaf samples was collected and physiological and biochemical changes were assayed.

\section{Relative water content assay}

Relative water content was measured, from each plant leaf discs were taken and weighted (fresh weigh, FW). The discs were then placed in distilled water for $5 \mathrm{~h}$ at $25^{\circ} \mathrm{C}$ and then their saturated weights (SW) were measured. The discs were then dried in oven at $70{ }^{\circ} \mathrm{C}$ for $24 \mathrm{~h}$ to calculate dry weight (DW). RWC were calculated by following formula:

$$
R W C=\frac{(F W-D W)}{S W-D W}
$$

\section{Membrane stability assay}

Leaf samples $(0.5 \mathrm{~g})$ were immersed into $10 \mathrm{ml}$ of -2 bar mannitol solution (14.7 g mannitol per liter) and after $24 \mathrm{~h}$ electrical conductivity of the solution was measured.

\section{Chlorophyll assay}

Chlorophyll was extracted in $80 \%$ acetone from the leaf samples according to the method of Arnon [17].

Proline assay

Proline content of leaves was determined according to a modification of the method of Bates et al [18].

\section{Antioxidant enzyme activity assay}

Catalase activity was estimated by the method of Cakmak and Horst [19]. Superoxide dismutase activity was determined according to the method of Giannopolitis and Ries [20].

\section{Lipid peroxidation assay}

The level of membrane damage was determined by measuring malondialdehyde (MDA) as the end product of peroxidation of membrane lipids [21].

\section{Protein peroxidation assay}

A standard dityrosine sample was prepared according to Amado et al [22].

\section{Statistical analysis}

All data were analyzed from analysis of variance (ANOVA) using the GLM procedure in SAS [23]. The assumptions of variance analysis were tested by insuring that the residuals were random, homogenous, with a normal distribution about a mean of zero. Duncan's multiple range tests was used to measure statistical differences between treatment methods and controls.

\section{RESULTS AND DISCUSSION}

Analysis of variance showed that the effects of irrigation withholding in different growth stages was significant on all measured traits and foliar application of salicylic acid was significant on all measured traits except for RWC and proline content (Table 2). In addition, interaction between these two factors was significant on measured traits experiment such as: catalase enzyme activity and malondialdehyde.

\section{Seed yield}

Seed yield decreased as result of irrigation withholding at stem elongation stage, irrigation withholding at flowering stage and irrigation withholding at seed filling period stage at by $6.46 \%$, $12.00 \%$ and $7.29 \%$, respectively with compared complete irrigation treatment conditions. Also, acceleration of flowering and maturity probably contributed to reduce the impact of drought stress in wheat plants. Similar findings have been reported in faba bean (Vicia faba L.) [24]. Seed yield increased as result of foliar application of salicylic acid with $300 \mu \mathrm{M}$ at by 5.86 when this treatment compared with untreated foliar application of salicylic acid (Table 3). Khodary [25] observed a significant increase in growth characteristics, pigment contents and photosynthetic rate in maize, sprayed with SA. Hussein et al [26] in their pot experiment sprayed salicylic acid to the foliage of wheat plants, irrigated with Mediterranean sea water and reported an enhanced productivity due to an improvement in all growth characteristics including plant height, number and area of green leaves, stem diameter and dry weight of stem, leaves and of the plant as a whole.

Relative water content 
Table 1: Soil properties of the experimental site

\begin{tabular}{ccccccccc}
\hline Depth & EC $\left(\mathrm{ds} \mathrm{m}^{-1}\right)$ & $\mathrm{pH}$ & $\begin{array}{c}\text { O.C } \\
(\%)\end{array}$ & $\begin{array}{c}\text { T.N.V } \\
(\%)\end{array}$ & $\begin{array}{c}\mathrm{K} \\
(\mathrm{ppm})\end{array}$ & $\mathrm{P}(\mathrm{ppm})$ & $\begin{array}{c}\text { Total N } \\
(\%)\end{array}$ & Texture \\
\hline $0-30 \mathrm{~cm}$ & 3.1 & 7.2 & 0.61 & $<10$ & 294 & 10.1 & 0.069 & Clay loam \\
\hline
\end{tabular}

Table 2: Analysis of variance on wheat attributes affected by irrigation withholding in different growth stages and foliar application of salicylic acid

\begin{tabular}{|c|c|c|c|c|c|c|c|c|c|c|}
\hline $\begin{array}{l}\text { Sources of } \\
\text { variation }\end{array}$ & $\mathrm{df}$ & $\begin{array}{l}\text { Seed } \\
\text { yield }\end{array}$ & $\begin{array}{l}\text { Relativ } \\
\text { e water } \\
\text { content }\end{array}$ & $\begin{array}{c}\text { Memb } \\
\text { rane } \\
\text { stabili } \\
\text { ty } \\
\end{array}$ & $\begin{array}{c}\text { Total } \\
\text { chlor } \\
\text { ophyl } \\
1 \\
\end{array}$ & Proline & $\begin{array}{c}\text { Super } \\
\text { oxide } \\
\text { dismu } \\
\text { tase } \\
\end{array}$ & $\begin{array}{c}\text { Catala } \\
\text { se }\end{array}$ & $\begin{array}{c}\text { Malond } \\
\text { ialdehy } \\
\text { de }\end{array}$ & $\begin{array}{c}\text { Dityro } \\
\text { sine }\end{array}$ \\
\hline Replication & 2 & $\begin{array}{c}3798.16 \\
\text { ns }\end{array}$ & $\begin{array}{c}0.009 \mathrm{n} \\
\mathrm{s}\end{array}$ & $\begin{array}{c}14.82 \\
\mathrm{~ns}\end{array}$ & $\begin{array}{c}0.004 \\
\mathrm{~ns}\end{array}$ & $\begin{array}{c}0.0000 \\
1 \mathrm{~ns}\end{array}$ & $\begin{array}{c}16.04 \\
\text { ns }\end{array}$ & $0.47 \mathrm{~ns}$ & $0.003 \mathrm{~ns}$ & $\begin{array}{c}0.000 \\
1 \mathrm{~ns}\end{array}$ \\
\hline Water stress & 3 & $\begin{array}{c}919071 . \\
27 * *\end{array}$ & $\begin{array}{c}127.33 \\
* *\end{array}$ & $\begin{array}{c}97400 \\
.21 * *\end{array}$ & $\begin{array}{c}215.9 \\
9 * *\end{array}$ & $\begin{array}{c}0.001 * \\
*\end{array}$ & $\begin{array}{c}14805 \\
9.49 * \\
*\end{array}$ & $\begin{array}{l}30639 \\
.44 * *\end{array}$ & $\begin{array}{c}126.93 \\
* *\end{array}$ & $\begin{array}{c}10.51 \\
* *\end{array}$ \\
\hline Error (a) & 6 & 6982.02 & 0.04 & 6.15 & 0.009 & $\begin{array}{c}0.0000 \\
04\end{array}$ & 7.68 & 2.27 & 0.0007 & 0.001 \\
\hline $\begin{array}{l}\text { Salicylic acid } \\
\text { application }\end{array}$ & 2 & $\begin{array}{c}402644 . \\
40^{*}\end{array}$ & $\begin{array}{c}0.523 n \\
s\end{array}$ & $\begin{array}{l}4589 . \\
26 * *\end{array}$ & $\begin{array}{c}1.87 * \\
*\end{array}$ & $\begin{array}{c}0.0000 \\
4 \mathrm{~ns}\end{array}$ & $\begin{array}{l}4489 . \\
44 * *\end{array}$ & $\begin{array}{l}3280 . \\
24 * *\end{array}$ & $\begin{array}{c}0.864 * \\
*\end{array}$ & $\begin{array}{c}0.310 \\
* *\end{array}$ \\
\hline Water stress $\times$ & & 11307.7 & $0.190 \mathrm{n}$ & 460.6 & 0.078 & 0.0000 & 367.3 & 270.2 & $0.131 *$ & 0.024 \\
\hline $\begin{array}{l}\text { Salicylic acid } \\
\text { application }\end{array}$ & 6 & $3 \mathrm{~ns}$ & $\mathrm{~s}$ & $1 \mathrm{~ns}$ & ns & $07 \mathrm{~ns}$ & Ons & $4 * *$ & & ns \\
\hline Error (b) & 16 & $\begin{array}{c}111955 . \\
53\end{array}$ & 1.030 & $\begin{array}{c}300.9 \\
1\end{array}$ & 0.103 & $\begin{array}{c}0.0000 \\
2\end{array}$ & $\begin{array}{c}453.4 \\
8\end{array}$ & 62.06 & 0.033 & 0.019 \\
\hline C.V $(\%)$ & & 15.52 & 1.34 & 2.01 & 1.13 & 7.82 & 2.64 & 4.21 & 1.83 & 3.09 \\
\hline
\end{tabular}

Table 3: Comparison of means on some attributes of wheat affected by irrigation withholding in different growth stages and salicylic acid foliar application.

\begin{tabular}{|c|c|c|c|c|c|c|c|c|c|}
\hline Treatment & $\begin{array}{c}\text { Seed } \\
\text { yield } \\
(\mathrm{kg} . \mathrm{ha} \\
-1)\end{array}$ & $\begin{array}{c}\text { Relati } \\
\text { ve } \\
\text { water } \\
\text { conten } \\
\text { t } \\
(\%)\end{array}$ & $\begin{array}{l}\text { Memb } \\
\text { rane } \\
\text { stabili } \\
\text { ty } \\
(\mu \mathrm{s} \\
\left.\mathrm{cm}^{-1}\right)\end{array}$ & $\begin{array}{l}\text { Total } \\
\text { chloro } \\
\text { phyll } \\
(\mathrm{mg} . \mathrm{li} \\
\left.\mathrm{t}^{-1}\right)\end{array}$ & $\begin{array}{l}\text { Prolin } \\
\mathrm{e} \\
\left(\begin{array}{l}\mathrm{mg} \cdot \mathrm{g}^{-} \\
\left.{ }^{1} \mathrm{FW}\right)\end{array}\right.\end{array}$ & $\begin{array}{c}\text { Superoxi } \\
\text { de } \\
\text { dismutas } \\
\text { e } \\
(\Delta \mathrm{A} / \mathrm{mg} \\
\text { pro.min } \\
\left.{ }_{1}\right)\end{array}$ & $\begin{array}{l}\text { Catala } \\
\text { se } \\
(\Delta \mathrm{A} / \\
\mathrm{mg} \\
\text { pro.mi } \\
\left.\mathrm{n}^{-1}\right)\end{array}$ & $\begin{array}{l}\text { Malon } \\
\text { dialde } \\
\text { hyde } \\
(\mathrm{nmol} \\
\mathrm{g}^{-1} \\
\mathrm{FW})\end{array}$ & $\begin{array}{c}\text { Dityro } \\
\text { sine } \\
\left(\mathrm{nmol}^{-1}\right. \\
\mathrm{g}^{-1} \\
\mathrm{FW})\end{array}$ \\
\hline Irrigation & $\begin{array}{c}6471 . \\
8 \mathrm{a}\end{array}$ & $79.62 \mathrm{a}$ & $\begin{array}{c}731.6 \\
2 \mathrm{~d}\end{array}$ & $\begin{array}{c}33.12 \\
\mathrm{a}\end{array}$ & $0.011 \mathrm{~d}$ & $652.88 \mathrm{~d}$ & $\begin{array}{c}122.0 \\
5 \mathrm{~d}\end{array}$ & $5.90 \mathrm{~d}$ & $3.32 \mathrm{~d}$ \\
\hline $\begin{array}{l}\text { Complete } \\
\text { Irrigation }\end{array}$ & $\begin{array}{c}6053 . \\
6 \mathrm{~b}\end{array}$ & $76.60 \mathrm{~b}$ & $\begin{array}{c}844.5 \\
7 \mathrm{c}\end{array}$ & $\begin{array}{c}31.58 \\
\mathrm{~b}\end{array}$ & $0.022 \mathrm{c}$ & $771.88 \mathrm{c}$ & $\begin{array}{c}160.9 \\
9 \mathrm{c}\end{array}$ & $7.80 \mathrm{c}$ & $3.86 \mathrm{c}$ \\
\hline $\begin{array}{c}\text { Irrigation } \\
\text { withholding at } \\
\text { stem elongation } \\
\text { stage }\end{array}$ & $\begin{array}{c}5695 . \\
1 \mathrm{c}\end{array}$ & $74.58 \mathrm{c}$ & $\begin{array}{c}882.7 \\
7 \mathrm{~b}\end{array}$ & $\begin{array}{c}26.21 \\
\mathrm{c}\end{array}$ & $0.036 \mathrm{~b}$ & $836.95 b$ & $\begin{array}{c}206.7 \\
2 b\end{array}$ & $\begin{array}{c}12.44 \\
b\end{array}$ & $4.95 b$ \\
\hline $\begin{array}{c}\text { Irrigation } \\
\text { withholding at } \\
\text { flowering stage } \\
\text { Irrigation } \\
\text { withholding at seed } \\
\text { filling period stage }\end{array}$ & $\begin{array}{c}5999 . \\
5 b c\end{array}$ & $70.66 \mathrm{~d}$ & $\begin{array}{c}983.4 \\
1 \mathrm{a}\end{array}$ & $\begin{array}{c}22.50 \\
\mathrm{~d}\end{array}$ & $0.042 \mathrm{a}$ & $960.22 \mathrm{a}$ & $\begin{array}{c}257.2 \\
1 \mathrm{a}\end{array}$ & $\begin{array}{c}13.83 \\
\mathrm{a}\end{array}$ & $5.72 \mathrm{a}$ \\
\hline $\begin{array}{c}\text { Salicylic acid foliar } \\
\text { application }\end{array}$ & $\begin{array}{c}5864 . \\
2 b\end{array}$ & $75.19 \mathrm{a}$ & $\begin{array}{c}879.9 \\
9 a\end{array}$ & $\begin{array}{c}27.94 \\
\mathrm{c}\end{array}$ & $0.025 \mathrm{a}$ & $785.00 \mathrm{~b}$ & $\begin{array}{c}170.9 \\
8 \mathrm{c}\end{array}$ & $\begin{array}{c}10.24 \\
\mathrm{a}\end{array}$ & $4.62 \mathrm{a}$ \\
\hline Untreated $(0 \mu \mathrm{M})$ & $\begin{array}{c}6071 . \\
4 a b\end{array}$ & $75.30 \mathrm{a}$ & $\begin{array}{c}860.9 \\
0 b\end{array}$ & $\begin{array}{c}28.39 \\
\mathrm{~b}\end{array}$ & $0.029 a$ & $808.00 \mathrm{a}$ & $\begin{array}{c}185.2 \\
9 \mathrm{~b}\end{array}$ & $\begin{array}{c}10.04 \\
b\end{array}$ & $4.46 b$ \\
\hline Treated $(150 \mu \mathrm{M})$ & $\begin{array}{c}6229 . \\
5 a\end{array}$ & $75.60 \mathrm{a}$ & $\begin{array}{c}840.8 \\
8 \mathrm{c}\end{array}$ & $\begin{array}{c}28.73 \\
\mathrm{a}\end{array}$ & $0.029 \mathrm{a}$ & $823.44 \mathrm{a}$ & $\begin{array}{c}203.9 \\
5 a\end{array}$ & $9.70 \mathrm{c}$ & $4.30 \mathrm{c}$ \\
\hline Treated $(300 \mu \mathrm{M})$ & $\begin{array}{c}6471 . \\
8 \mathrm{a}\end{array}$ & $79.62 \mathrm{a}$ & $\begin{array}{c}731.6 \\
2 \mathrm{~d}\end{array}$ & $\begin{array}{c}33.12 \\
\mathrm{a}\end{array}$ & $0.011 \mathrm{~d}$ & $652.88 \mathrm{~d}$ & $\begin{array}{c}122.0 \\
5 \mathrm{~d}\end{array}$ & $5.90 \mathrm{~d}$ & $3.32 \mathrm{~d}$ \\
\hline
\end{tabular}

RWC decreased as result of irrigation withholding at 
different growth stage (Table 3). RWC is the appropriate measure of plant water status in terms of the physiological consequence of cellular water deficit, while water potential is an estimate of plant water status and it is useful in dealing with water transport in the soil-plant-atmosphere continuum [27].

\section{Total chlorophyll}

The highest total chlorophyll content was related to those plots which were treated with complete irrigation. However irrigation withholding at different growth stages decreased total chlorophyll content. Changes in leaf chlorophyll content with drought and heat injury may involve a severe

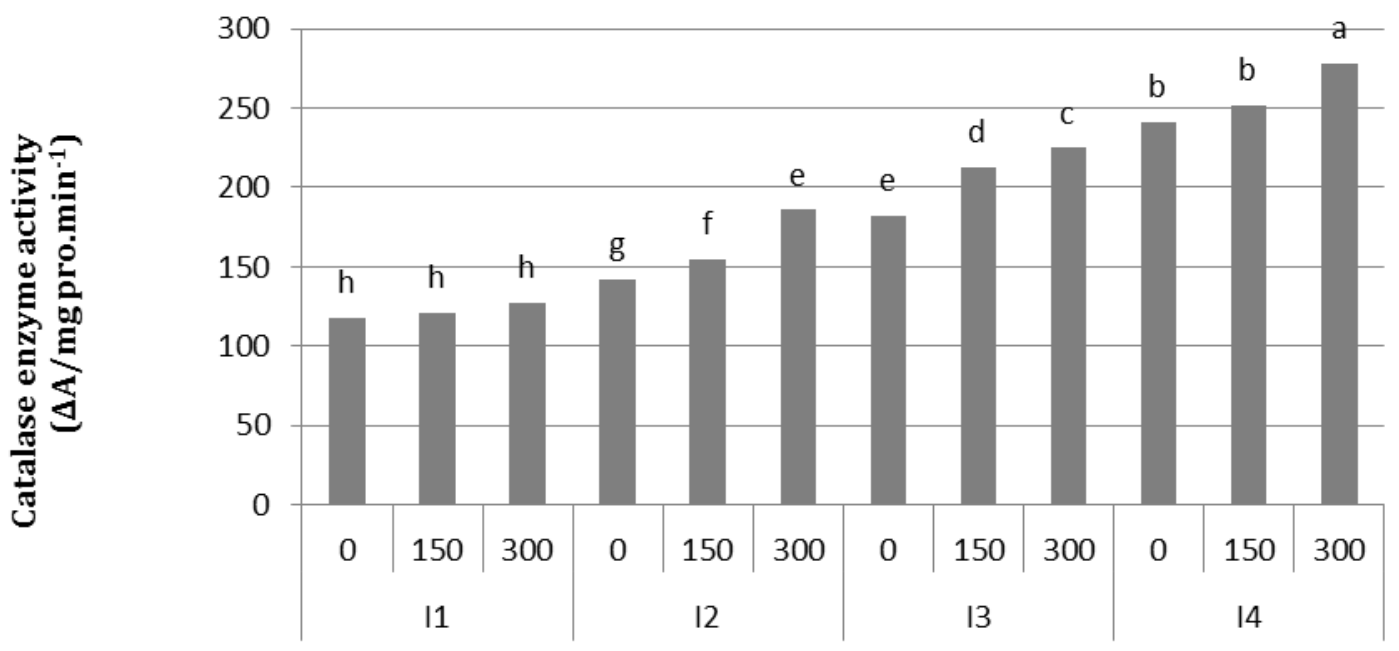

Figure 1: Interaction between irrigation withholding in different growth stages and foliar application of salicylic acid on catalase enzyme activity (I1 =complete irrigation, I2= withholding at stem elongation stage, I3= withholding at flowering stage and I4= withholding at seed filling period stages and 0, 150 and 300 salicylic acid concentrations ). All the values followed by the same letter in each column are not statistically different at the $\mathrm{P}<0.05$ probability level.

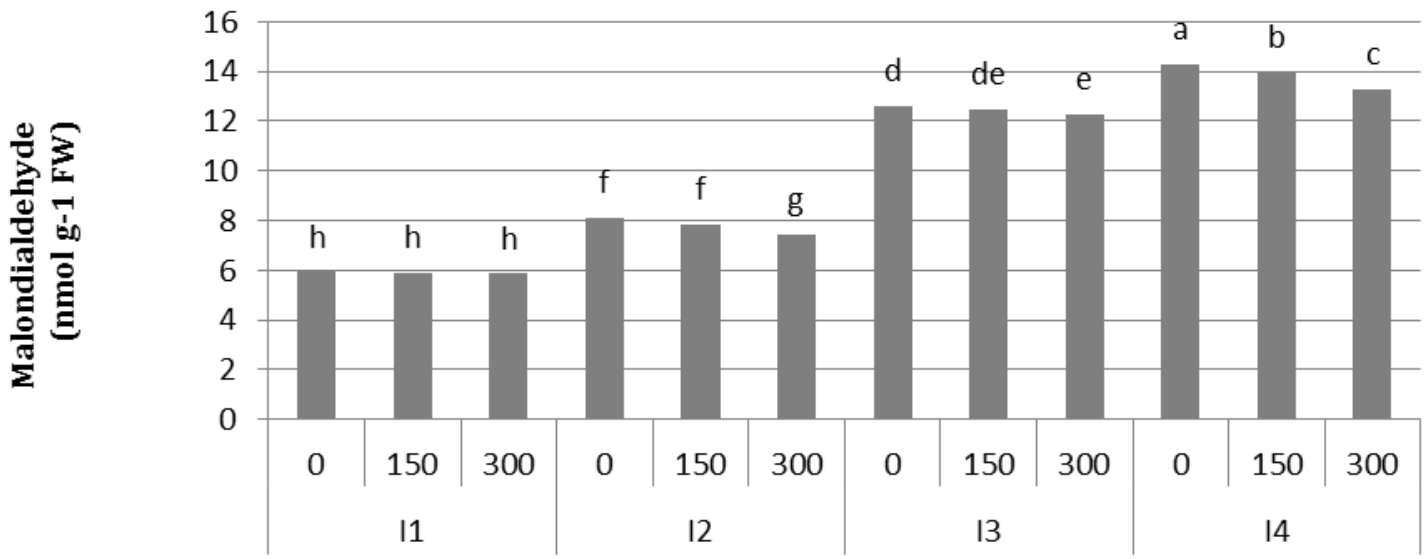

Figure 2: Interaction between irrigation withholding in different growth stages and foliar application of salicylic acid on malondialdehyde. (I1 =complete irrigation, I2 = withholding at stem elongation stage, I3= withholding at flowering stage and $\mathrm{I} 4=$ withholding at seed filling period stages and 0,150 and 300 salicylic acid concentrations ). All the values followed by the same letter in each column are not statistically different at the $\mathrm{P}<0.05$ probability level.

\section{Membrane stability}

According to table 3 the highest electrolyte leakage was occurred when wheat plants were treated with irrigation withholding at different growth stages. Electrolyte leakage decreased as result of foliar application of salicylic acid when these treatments compared with untreated foliar application of salicylic acid (Table 3). All this shows that foliar application of salicylic acid can lower the plant's membrane permeability and alleviate the damage on the cell membrane caused by water stress. chlorophyll photooxidation mediated by oxyradicals [28]. Water deficit stress leads to an increase in free radicals in chloroplasts and destruction of $\mathrm{Chl}$ molecules by ROS, which results in reduction of photosynthesis and growth. Singlet oxy gen atoms and $\mathrm{O}_{2}^{-}$radicals predominantly attack double bondcontaining compounds (unsaturated fatty acids and Chl), thus damaging the chloroplast membrane system and photosynthetic reaction centres [29]. It is worth mentioning that total chlorophyll content increased as result of foliar application of salicylic acid with $300 \mu \mathrm{M}$ when these treatments compared 
with untreated foliar application of salicylic acid in this condition (Table 3). Salicylic acid is a detoxifier and neutralizer of superoxide radicals and other singlet oxygen species; by prevention of the activity of free radicals it can enhance the Chl content. Moreover, salicylic acid significantly increased chlorophyll a \& b and carotenoids [30,31].

\section{Proline}

The result showed that the highest proline content in the leaves of plants belongs to irrigation withholding at seed filling period stage (Table 3). PRO protects membranes against the adverse effect of high concentrations of ions and may also function as a PROT compatible hydrotrope and as a hydroxyl radical5scavenger [32]. In the current study, irrigation withholding at different growth stages increased the leaf PRO content. The concentration of this metabolite usually increases in response to water deficit stress [33].

\section{Antioxidant enzymes}

Plants under irrigation withholding at different growth stages showed a significant increase in SOD and CAT activity in the leaves compared with control plants (Table 3). Application of salicylic acid was associated with a significant difference in SOD and CAT activity in stressed plants; however, application of salicylic acid increased SOD and CAT activity in plants (Table 3 and Figure 1). However as can be seen from figure 1 the highest catalase enzyme activity was obtained from foliar application of salicylic acid with $300 \mu \mathrm{M}$ concentration in irrigation withholding at different growth stage condition. The enzymes assayed are scavengers of free radical species. SOD converts one form of ROS $\left(\mathrm{O}_{2}{ }^{-}\right)$to another equally toxic one $\left(\mathrm{H}_{2} \mathrm{O}_{2}\right)$. Hydrogen peroxide is converted to oxygen and water by CAT and POX [34]. The increase in SOD activity was reported in tolerance basmati rice variety [35]. In our study, salicylic acid increased the activity of these enzymes maybe by elimination of free radicals. This increased antioxidant enzyme activity might be due to SA's regulatory role at transcriptional and translational levels. Also, these increases might be due to their direct scavenging function against the toxic free radicals and their promotional effects on synthesis of internal protective antioxidants. SA was found to enhance the activities of antioxidant enzymes, CAT, peroxidase (POX) and superoxide dismutase (SOD), when sprayed exogenously to the drought stressed plants of L. esculentum [10] or to the salinity stressed plants of B. juncea [15].

\section{Lipid and protein peroxidation}

The level of lipid and protein peroxidation of leaves, measured as MDA and dityrosine (DT) content, are shown in Table 3. The levels of MDA and DT were increased in the leaves of plants by irrigation withholding levels. The highest MDA and DT content belong to irrigation withholding at seed filling period stage. One of the best known toxic effects of ROS is damage to cellular membranes, lipids and PROTs. Plasma membranes are oxidized by ROS to generate MDA. In this study, water deficit stress induced a progressive accumulation of MDA and DT in the leaves of plants. We observed a significant increase in the MDA and DT content in water deficit stressed plants. It was observed that application of salicylic acid decreased the MDA and DT content in the leaves of plants (Table 3 and figure 1). Exogenous salicylic acid partially inhibits these increases because salicylic acid is a scavenger of ROS. SA also affects the lipid peroxidation, which plays a key role in initiating defense response [36].

\section{REFERENCES}

1. Alam MJ 2001: Effect of exogenous enzyme in diet on broiler performance. M.S. Thesis, Dept. of Poultry Science, BAU, Mymensingh2202.

2. Kies AK, Vanhemert KAF, Sauer WC 2001: Effect of phytase on protein and amino acid digestibility and energy utilization. World's Poultry Science Journal 57 109-124.

3. Bedford MR 1995: Mechanism of action and potential environmental benefits from the use of feed enzymes. Animal Feed Science and Technique 53 145-155.

4. Toghyani M, Mohammadsalehi A, Gheisari A, Tabeidian SA 2009: The effect of lowglucosinolaterapeseed meal in diets with multi-enzyme supplement on performance and protein digestibility in broiler chicks. Journal of Animal and Feed Science 18(2) 313-321.

5. Ward NE 1996: Commercial vitamin supplementation for poultry. Poultry Adviser, New Jersey, USA. 29(3) 29-50.

6. Lee DN, Ching FW, Shiau-RUL, Hen WW 2008: Effect on growth performance immune response and gastrointestinal health of Taiwan red feathered native chickens feed diets supplementation with growth promoting antibiotics. Journal China Social Animal Science 37 223-224.

7. Salahuddin M, Miah MA, Ahmad N 2012: Effect of protein and vitamin A, D, E on growth performance and hemato-biochemical parameters on broiler. Bangladesh Journal of Veterinary Medicine 10 (1-2) 10-14.

8. Downs KM, Norton RA, Maclin KS, Hess JB 2003: Potential of vitamin $\mathrm{E}$ and zinc-amino acid complex for the reduction of cellulitis in broilers. Journal of Applied Animal Research. 23(1) 25-32.

9. Hosamani SV, Shivakumar MC, Kulkarni VS, Harapanahalli MD 2001: Effect of supplementing dietary enzyme on the performance of broilers. Karnataka Journal of Agricultural Sciences 14(4) 1046-1048. 
10. Villar PG, Diaz CA, Avila GE, Guinzberg R, Pablos JL, Pina E 2000: Effects of dietary supplementation with vitamin $\mathrm{C}$ or vitamin $\mathrm{E}$ growth performance in broilers at risk of developing ascites syndrome. American Journal of Veterinary Research 63(5)673-676.

11. Shlig AA 2009: Effect of vitamin E and selenium supplement in reducing aflatoxicosis on performance and blood parameters in broiler chicks. Iraqi Journal of Veterinary Sciences 23 97-103.

12. Singh H, Sodhi S, Kaur R 2006: Effects of dietary supplements of selenium, vitamin $\mathrm{E}$ or combinations of the two on antibody responses of broilers. Poultry Science 47(6) 714-719.
13. Choct M, Naylor AJ 2004: Effect of dietary selenium and vitamin $\mathrm{E}$ levels on performance of male broilers. Asian Australia Journal of Animal Science 17 1000-1006.

14. Swain BK, Johri TS, Majumdar S 2000: Effect of supplementation of vitamin E, selenium and their different combinations on the performance and immune response of broilers. Poultry Science 41(3) 287-292.

15. Sahin N, Sahin K, Kucuk O 2001: Effects of vitamin $\mathrm{E}$ and vitamin A supplementation on performance, thyroid status and serum concentrations of some metabolites and minerals in broiler reared under heat stress $\left(20^{\circ} \mathrm{c}\right)$. Veterinary Medicine 46(11-12) 286292. 